\title{
A critical engagement with the DSM-5 and psychiatric diagnosis
}

\author{
Susan Kriegler \& Suzanne E Bester \\ (Department of Educational Psychology,) University of Pretoria, SA \\ Corresponding author: \\ Suzanne E Bester, Department of Educational Psychology, University of \\ Pretoria, Aldoel 2-2, Groenkloof Campus, C/O George Storrar Road \&Leyds \\ Street, Pretoria, 0002, South Africa \\ Telephone: +27-12-420-3891 \\ Fax: $\quad+27-12-420-5511$ \\ Email: $\quad$ suzanne.bester@up.ac.za
}

\begin{abstract}
:
Classifications in psychiatry can result in the reification of hypothetical approaches, arbitrary categorization and social injustice. This article applies a social constructivist approach to critique the DSM-5 as a neurobiological model of psychiatric diagnosis which ignores psychosocial factors such as poverty, unemployment and trauma as causes of mental distress. It challenges the universality of psychiatric diagnosis and proposes that cultural psychiatry's framing of 'culture-bound syndromes,' or 'cultural case formulation' guidelines, is oversimplified. Use of the DSM in the South African context risks perpetuating injustice by labeling and stigmatizing people who have in the past been racially stigmatized by apartheid. In culturally diverse South Africa, psychiatric diagnosis should take into account alternative explanatory models that provide a more balanced view of the complex and dynamic relationship between biological and sociocultural forces in the manifestation of psychopathology.
\end{abstract}


Keywords: Categorization, classification, criticism/critique of DSM, culture, DSM-5, psychiatric disorders

Psychiatric classification and its value as well as consequences have been an ongoing debate in the history of psychiatry. The Diagnostic and Statistical Manual of Mental Disorders (DSM) and the International Classification of Diseases (ICD) are two diagnostic tools used by clinicians in psychiatry, and it is more specifically the DSM, prepared by the American Psychological Association (APA) and now in its fifth version, that is regarded as the dominant classification system in the world (Cross \& Walsh, 2012; Maldonado, González, Castillo, \& Jaurez, 2011).

The opportunity to revise diagnostic criteria in psychiatry occurs on average once every 10-20 years (Hebebrand \& Bulik, 2011). The period leading up to the revision of the diagnostic criteria is typically marked by a review of the existing diagnostic criteria by the APA. It also involves the self-mobilization of experts from various fields in clinical practice who were not invited by the APA to participate directly in the review process but who want to contribute their opinions and suggestions in the hope that they will be taken into consideration by the APA. Understandably, this period is marked by intensive debate on and criticism of the existing inconsistencies and deficiencies of the DSM classification system and its validity, reliability, and relevance across cultures, ethnicities, genders, socioeconomic groupings, and languages (Maldonado et al., 2011).

\section{Setting the scene for the publication of the DSM-5}

The DSM-IV-TR (2000) was preceded by the original DSM (in 1952), then by the DSM-II (1968), the DSM-III (1980), the DSM-III-R (Third Edition Revised) (1987) and the DSM-IV (1994). The DSM has a powerful influence on psychiatry praxis, other mental health 
professions and people diagnosed with mental disorders. It also has much in common with the World Health Organization's (WHO) taxonomy - Chapter V of the (ICD-10) (LópezMuñoz, Alamo, Quintero-Gutiérrez, \& García-García, 2008). Due to its wide influence, the DSM has earned the name 'the Bible of psychiatry' (Dhar, 2013), but not everyone is a believer (Toor, 2013). When the American Psychiatric Association (APA) published the updated diagnostic and Statistical Manual of Mental Disorders (APA, 2013), critics of the DSM-5 spotlighted the lowering of diagnostic thresholds for existing disorders and the introduction of disorders that may lead to inappropriate medical treatment of vulnerable populations.

The broader aims of classifications in psychiatry are to optimize research and facilitate communication between researchers and clinicians at national and international levels through the use of a clearly defined nomenclature; to provide a nosographical reference system that can be used for diagnosis, prognosis and planning treatment; and for statistical records for public health institutions (Lempérière, 1995). However, Lempérière's warning in 1995 that classifications in psychiatry may become reductive academic exercises, dehumanizing labelling systems, or potential sources of social and political violence is still relevant today (Kecmanovic, 2012). The storm of protest against the DSM-5 included concerns about empirical evidence, transparency, field trials, links with the pharmaceutical industry, and, most fundamentally, the biomedical definition of mental disorder.

Employing a social constructivist perspective, this article seeks to problematize the possible impact of the psychiatric biomedical model in previously colonized African countries. As a paradigm, social constructivism has been highly influential in the deconstruction of psychiatric diagnosis and treatment, particularly in the development of feminist and anti-racist critiques (Bendelow, 2004). A social constructivist perspective 
enables us to explore the complex and dynamic relationship between biological and sociocultural forces in the manifestation of psychopathology.

The article addresses unresolved ontological and epistemological questions that undermine the basis of classification in psychiatry, and psychiatry's power to Westernize mental illness globally. Whether it is applied as 'culture bound syndromes,' or as 'cultural case formulation' guidelines, cultural psychiatry's framing of sociocultural processes - as merely epiphenomenal - is oversimplified. In a continent shattered by political and economic problems that are the legacy of colonial exploitation, and where women in particular are exposed to a variety of social and cultural factors that disadvantage, devalue and disempower them, it is debatable whether 'neuropsychiatric disorder' is always an appropriate label. This article proposes alternative explanatory models that provide a more balanced view of the ways in which context shapes the developing, plastic brain and suggest new possibilities for conceptualizing, preventing and treating mental disorders.

Specifically, the article critiques the cultural relevance of the DSM-5 in the South African context - a country with widely diverse cultural and social needs. Increasing DSMbased diagnostic labeling, while underplaying the impact of cultural, economic, political and social ecologies, would be one more way of perpetuating the past injustices of apartheid. The case of South Africa illustrates that the jury will be out on what truly constitutes psychopathology across cultures. More progress is needed in culture-sensitive research and in understanding the complex and dynamic relationship between biological and sociocultural forces in the manifestation of psychopathology.

This is a scoping review meant to highlight points of consensus about the subject matter and also to flag aspects in need of further research investigation. Thus the study is essentially exploratory and indicative in its approach. We narrowed our scope of review to the period 2000-2013. Any research cited prior to this period was cited because the authors 
considered it important in informing current opinion and casting light on historical facts pertaining to the publication of the DSM.

\section{Unresolved ontological/epistemological debates}

The underlying problem of the DSM is that it is to a large extent based on opinion and cannot claim to be a medical diagnostic system driven by science (Coalition for DSM-5 Reform, n.d.; Frances, 2013; Kirschner, 2013; Levine, 2013; Seaman, 2013). The evolution of the DSM is a story of the struggles of the American Psychiatric Association to gain respectability within medicine and achieve dominance among mental health professionals (Kutchins \& Kirk, 1997). Despite this, within the tradition of medical semiotics, the DSM-5 treats symptoms and complaints as if they were objective indicators of underlying syndromes or diseases independent of time, individual, and culture (Vanheule, 2012). As De Vos (2010, p. 544) has said, at the presumed "zero level of subjectivity", symptoms are offered as already answered technical questions.

The current battle represents a long-simmering conflict in psychiatry that goes public at DSM revision time (Dhar, 2013). For example, in an aggressive media campaign, the APA announced that the then new DSM-III (1980) would remedicalize psychiatry and offer a defence of the medical model as applied to psychiatric problems. The reason given for the revision was the need to keep up with science (Angell, 2011). Proposed new categories resulted in fierce debates in the past, for instance feminists successfully contested a category of 'rapism' proposed for the DSM-III-R (Caplan, n.d.). Similarly, a committee was appointed to consider whether 'racism' should appear in the DSM-5, a step that would disguise a social evil by making it seem an individual mental illness (Profit, 2004).

More fundamentally, Goldarce (2010) notes that the current debate smacks of an outdated Cartesian dualism that has crept back with the assumption that a psychological or 
behavioural condition has a biological aetiology. Kendell (2001) suggests that the practice of dichotomizing illness into mental and physical categories is archaic, deeply misleading and incompatible with contemporary understanding of disease. Despite the apparent incremental improvements in the conceptual basis of classification in psychiatry (First, 2010), much of the present-day discussion is a replay of debates that have not been resolved since the inception of scientific psychiatry and that continue to cast a long shadow on both the DSM and ICD revisions (Jablensky, 2012).

From a Chinese perspective, Lee (2001) questions the assumptions of Western psychiatry, including the feasibility of a neo-Kraepelinian taxonomy based on adherence to the mind-body dichotomy. Likewise, Turner (2003) critiques the simplistic Hempelian neopositivism that still informs current scientific psychiatry's deductive-nomological model of scientific explanation. In 1996, Littlewood wrote an in-depth analysis of psychiatry's unresolved ontological and epistemological dilemmas that is still relevant today, particularly in the context of cultural differences.

\section{Cultural loading}

Some non-Western cultures understand mental health and illness in more holistic and often spiritual ways (Ally \& Laher, 2008), thus underlining the fact that the biomedical model is a Western cultural construct to begin with. Rhi (2001) emphasizes the essential religious and spiritual meaning of mental illness, especially in cultures undermined by modernism and secularism. Rhi (2001) further postulates that reason and objectivity have emerged as new spirits. "Scientists have been religiously devoted to the new deities without recognizing that what they themselves are now experiencing is in fact a new myth" (Rhi, 2001, p. 575).

Heine (2001) warns that a psychology based on American individualism stands the risk of developing an understanding of the self that is peculiar in the context of the world's 
cultures. The biomedical understandings of the mind and the body stand in sharp contrast to, for example, aboriginal understandings that value the balance of physical, emotional, mental and spiritual wellbeing and interconnectivity to family, community and the land (Hughes, 1993; Vukic, Gregory, Martin-Misener, \& Etowa, 2011). Lin, Smith, and Ortiz (2001) point out that discrepancies in the conceptualization of health problems between medical professionals and the public is not limited to ethnic minority populations as evidenced by the resurgence of interest among the public in alternative and complementary medicine.

\section{Medicalizing normality}

Carroll (2013), the Coalition for DSM-5 Reform (n.d.), Davey (2013) and Frances (2013) believe that the DSM-5 will cause diagnostic inflation, precipitate fad diagnoses, medicalize normality and make mental disorder virtually ubiquitous. Psychiatry's failure to deal with the problem of false positive diagnoses of mental disorder has been demonstrated in the past (Wakefield, 2010). In a survey conducted by Kesler, Chiu, Demler, \& Walters (2005) based on the DSM, it was found that nearly every second American (48\%) suffers from at least one mental illness during his or her lifetime. Apart from helping psychiatry better resemble the rest of medicine (Davey, 2013), the only beneficiary of the creation of 'false positive' epidemics through over-diagnosis is the pharmaceutical industry (Jabr, 2013).

Psychiatry's 300\% increase in mental disorders in the DSM over five decades has generated billions of dollars in government funding. Since DSM-IV, there has been a $256 \%$ increase in psychiatric (antipsychotics and antidepressants) drug sales (Citizens Commission on Human Rights International [CCHR], 2013). In particular, a vast expansion has occurred in the use of second-generation antipsychotic drugs in patients of all ages, particularly young people. Until recently, these drugs were used to treat just a few serious psychiatric disorders. But now they are prescribed for conditions as varied as mild mood disorders, everyday 
anxiety, insomnia and even mild emotional discomfort, notwithstanding the fact that these drugs have serious side effects of their own (Friedman, 2012).

Frances (2013) warns that the diagnosis of Disruptive Mood Dysregulation Disorder may exacerbate the already excessive use of medication in young children. During the past two decades, child psychiatry has already generated three fads - a tripling of Attention Deficit Disorder, a more than 20 times increase in Autistic Disorder and a 40 times increase in childhood Bipolar Disorder (Caplan, n.d.; Lane, 2013; Wedge, 2011). The already fuzzy boundary between Generalized Anxiety Disorder and the worries of everyday life is obscured, potentially creating millions of anxious new 'patients.'

\section{Stigmatization}

The BPS (2011) concedes that some people find a diagnostic label helpful, feeling that their problems are recognized, validated, explained and that there is promise of relief. However, other people often find that diagnosis offers only a spurious promise of such benefits and find themselves stigmatized instead (Joyce, 2008). Various studies (Dietrich et al., 2004; Read, Haslam, Sayce, \& Davies, 2006) have found that people who tend to believe in a biological or genetic cause are more likely to see those with mental health problems as unpredictable and dangerous, and to avoid interacting with them. Jo Phelan (2002) explains that biological attributions can increase stigma, for example by making the ill person seem physically distinct, almost a different species. Biological attributions can also create an associative stigma for the whole family.

\section{Globalization influences}

Rapid globalization of the psychiatric biomedical model has shaped cultural history thereby confirming Strand's characterization of DSM classification as a "way of world making" 
(Strand, 2011, p. 274). The model has, for example, made depression the master narrative of mental health worldwide (Lee, 2002), thus underscoring Blackman's (2007) view that psychiatric culture provides an important site for research in the humanities, and highlighting Cabassa (2003) and Martínez-Hernáez (2006) call for an examination of clinician bias.

Because the community or specialists respond to particular kinds of patient presentation, the disorders quickly conform and multiply according to the expectations of experts (Downey, 2010). Psychiatry itself may thus be seen as a powerful molding force that shapes the culture in which it operates while, ironically, attributing the disorders, often created by itself, to brain dysfunctions.

Watters (2010) points out that the way the world goes mentally ill is being homogenized. The mass media (Caracci \& Mezzich, 2001) and the women's magazine culture (Blackman, 2004), in particular, have probably played no small role in this phenomenon. Behind the promotion of Western ideas of mental health lie a host of cultural assumptions about human nature (Ally \& Laher, 2008; De Vos, 2010; Duniec \& Raz, 2011; Lasch, 1978). Offering the latest Western mental health theories in an attempt to ameliorate the psychological stress sparked by modernization and globalization is not a solution; it may, in fact, be part of the problem (Watters, 2010). Rhi (2001) likewise challenges the arrogance and self-righteousness that attends psychiatry's claim to be a social enlightenment movement. When local conceptions of the self and modes of healing are undermined, the disorienting changes that are at the heart of much of the world's mental distress are accelerated (Watters, 2010).

\section{Pathologizing post-colonial stress}

For example, Olatawura (2001) describes the havoc that globalization has caused in Africa where traditional social structures are undermined by the disruptive effects of modernization. 
The psychologically destructive effects of cultural hybridization and capitalist commodification on African communities create a mix of disturbing phenomena in a continent shattered by political and economic problems that are the legacy of colonial exploitation (Olatawura, 2001). Loudon (1959) describes how in the Zulu culture in South Africa, the communal ritual of nomkubulwana, which had served to resolve intergender tensions ceremonially, became attenuated into individual patterns of neurotic anxiety ufufunyana - among the women who were forced to become household heads because the men had to leave their tribal homes to seek work in the cities. This is merely one example of how white colonization may have induced stress in preindustrial systems and pathologized the whole social field to the extent that the idiom in which the relations between the sexes (and races) is expressed has become one of individual pathology.

Caracci and Mezzich (2001) also describe how in large, culturally pluralistic urban centres in Latin America, poverty, inequality, family dislocation, violence against women and children, abusive substances and awareness of deprivation undermine social order and psychological stability. Fàbrega (2001) maintains that the blurring of national boundaries and a lessening of the authority and integrity of separate cultures have paved the way for the universal credo of science and modernity in psychiatry. However, culture-bound syndromes reported in non-Western societies remain a focus of contention over the validity and universality of psychiatric diagnosis (Lee, 2002).

\section{Culture-bound syndromes}

In 1994, the APA introduced an appendix of 25 culture-bound syndromes in the DSM-IV. However, many scientists contested the notion that culture-bound syndromes are unique conditions, arguing that most of them may be variants of disorders already known in Western 
culture by different labels (Lilienfeld \& Arkowitz, 2009). For example, López-Ibor (2003) states that it is only the cultural halo that makes culture-specific disorders attractive.

At the other end of the spectrum of opinions, Littlewood (1996) argues that clinical understandings of culture derive largely from imperial medicine, which had applied the distinction between the biological form and the cultural content to local illnesses that could not easily be fitted into the European nosology.

Conspicuously, the discussion of culture-bound syndromes usually treats other people's syndromes as culture-bound while assuming that Western psychological illnesses are not culture-bound (Hughes, 1993). In fact, Western history is replete with examples of truly odd psychiatric illnesses that Westerners seem to be vulnerable to for short periods of time (Downey, 2010; Rhi, 2001). One of the myths of Western psychiatry is that various unusual culture-specific disorders whose biological bases are uncertain occur only in exotic places outside the West (Wallace, 2009). In this regard, Arnett (2008) argues that United States (US) psychological research focuses too narrowly on Americans, who constitute less than five percent of the world's population.

\section{Local heritages.}

There is a rich literature in cross-cultural psychiatry that examines how the presentation of symptoms and the expression of disorders, as well as help-seeking behaviours, vary across cultures (Cabassa, 2003). However, trans- and cross-cultural research is hindered by a host of problems that make comparison and generalization almost impossible. The first difficulty in attempting to answer the question of epidemiological variability is that cross-cultural comparative studies are plagued by problems regarding sampling, accessibility of populations, and reliability and validity of diagnoses (Hinton \& Lewis-Fernández, 2011; Joyce, 2008; Olatawura, 2001). For example, a review of the literature since 1994 on cultural 
or race/ethnicity-related factors that may limit the universal applicability of the diagnostic criteria for anxiety disorders revealed mismatches between the DSM criteria and the local phenomenology in specific cultural contexts (Lewis-Fernández et al., 2010).

Rossier, Ouedraogo, Dahourou, Verardi, and De Stadelhofen (2013) also point to the difficulty, when conducting research in Africa, of assessing measurement equivalence. Among other problems, translating a complex psychological inventory into a native African language is a demanding task. In addition, there are different cultural norms for what is considered deviation. Caracci and Mezzich (2001) report that the International Pilot Study of Schizophrenia (IPPS) was designed to compare transculturally over 1200 patients in nine countries, using rigorous and culturally adapted methodology, and found that schizophrenics in developing countries tend to have less severe courses and outcomes than those in developed countries, possibly reflecting different levels of tolerance for mental illness and better support systems, especially the family.

Methodological difficulties may explain why comparative studies have tended to focus on intergroup differences within multicultural societies rather than on differences between cultures or countries. For example, studies in the Netherlands (Fassaert et al., 2010) and in England (Bhui, McKenzie, \& Gill, 2004) found that the presentation, management and outcome of mental disorders differ between ethnic groups, but that these disparities may well be partly related to institutional racism in mental health services. Other comparative studies (Dinos et al., 2009; Bhui et al., 2011; Bhui et al., 2012) identified numerous socioeconomic risk factors such as poverty, hostility and residential instability, which, apart from cultural or ethnic factors, render minority groups more vulnerable than White people. 


\section{Limitations of cultural psychiatry}

Notwithstanding its focus on culture as indicated by its name, classical, conservative cultural psychiatry tends to underscore the biological, or medical, causes of mental illness, which is viewed as a universal problem cloaked in the attire of culture. The cultural tradition within cultural psychiatry, however, is inclined to argue against the appropriateness of a universal system of concepts regarding mental disorder and, with its roots in the social and cultural sciences, tends to move in the direction of cultural relativism (Fàbrega, 2001). Fàbrega (2001) hopes that a viable and flourishing international cultural psychiatry will be able to integrate the two seemingly opposed perspectives. This, Fàbrega (2001) proposes, can be accomplished by adding sensitivity to and appreciation of cultural differences to the neurobiological paradigm.

An example of such an attempt is provided by Lee (2001) who explains how, in the case of China, the Chinese Classification of Mental Disorders (CCMD)-3 system endeavours to achieve global unification while at the same time preserving features that are salient for local application. Examples of Latin American attempts to achieve the same objective include the use of explicit operational criteria in Chile, the proposal of a multiaxial diagnostic formulation in Brazil, the Cuban Glossary of Psychiatry and the Latin American Guide for Psychiatric Diagnosis (GLADP) (Berganza et al., 2001).

Another example of the ideal of adding sensitivity to and appreciation of cultural differences to the neurobiological paradigm, as proposed by Fàbrega (2001), is the way in which migrants and refugees are supposed to be treated in host countries. Wintrob (2010) notes that the growth in interest in cultural psychiatry has in large part been due to the steady increase in the migration of the world's population from low-income to higher income regions and countries that have compelled mental healthcare providers to meet the needs of their increasingly culturally diverse populations. Hence, the practical application of cultural 
psychiatry involves the open-ended questioning of patients and their families in order to identify features of race, ethnicity, religion and socioeconomic class, as well as immigration history and acculturative stress (Rasmussen, 2012).

In the DSM-IV-TR, 'Cultural Formulation' guidelines are proposed on how clinicians should conceptualize the role of culture in patients' mental health problems. The guidelines appeared first in the DSM-IV (1994) in the form of the Outline for Cultural Formulation (OCF) glossary of Culture-Bound Syndromes, which were placed at the back of the book (Messich et al., 2001).

The DSM-IV (1994) is regarded by some as "a watershed moment for cultural psychiatry" (Lim, 2013, p. 1) and it is based on the OCF that the DSM-5 could advance cultural psychiatry by introducing the Cultural Formulation Interview (CFI) which was proposed by the SSPC. The CFIis a 16-question interview with 12 supplementary modules which is based the principles of a person-centred assessment in which culture is regarded as an important variable.

This advancement in the DSM-5 certainly reflects a concerted effort to place culture in the DSM-5 (Rasmussen, 2012). However, the following question was posed by some of the members of the SSPC: How is this different from ordinary, good diagnostic practice? Alarcón et al. (2009) called for a sociocultural perspective throughout the manual. It was pointed out that most patients express distress in culturally embedded ways, which differ by region, age, gender, and local conditions and traditions (Messich et al., 2001).

A more in-depth example of the application of cultural psychiatry is the 'shared care' model in indigenous minorities where every effort is made to establish a collaborative relationship with traditional healers in the community (Vukic et al., 2011). The model also attempts to deal with broader determinants of poor mental health such as poverty, social exclusion, poor education, unemployment and housing problems, as well as historical factors 
such as colonization, residential schools and racism.

Littlewood (2001), in discussing issues of repression, possession and oppression, argues that the obvious first option for intercultural work - to continue to provide some accessible form of traditional healing - looks dubious because a multicultural society already embodies competing realities for dominant and subdominant groups alike.

Prospective for a culturally responsive nosology

Careful attention to the sociocultural dimensions of mental illness accordingly serves both a scientific and social justice agenda (Alarcón et al., 2009). For example, when assessment fails to attend to sociocultural factors, it risks misdiagnosis and the perpetuation of stereotypes based on race, ethnicity, gender, religion and sexual orientation. Data demonstrating elevated rates of misdiagnosis of schizophrenia among African-Americans provide a sobering illustration of culturally uninformed practice. Littlewood (2001, p. 508) highlights our refusal to acknowledge the political and poses the question: "Is depression in people who see themselves as oppressed an abnormal response?"

Regarding oppression, social psychologists point to a variety of social and cultural factors that collectively disadvantage, devalue and disempower women (Barnett \& Rivers, 2004; Fine, 2011). It should not be surprising that, according to the WHO (2013), gender is correlated with the prevalence of many mental disorders including depression and anxiety. Unipolar depression, predicted to be the second leading cause of disability globally by 2020 , is twice more common in women than in men. It is indeed questionable why the WHO (2013) insists on calling depressive disorders among women 'neuropsychiatric disorders' while at the same time stating that gender-specific risk factors for mental health that disproportionately affect women include gender-based violence, socioeconomic 
disadvantage, low income and income inequality, low or subordinate social status and unremitting responsibility for the care of others.

The high prevalence of sexual violence against women renders women the largest single group affected by Post Traumatic Stress Disorder (PTSD). Incidentally, the WHO (2013) adds that an estimated $80 \%$ of the 50 million people affected by violent conflicts, civil wars, disaster and displacement are women and children.

When we consider mental health problems with no obvious biological component, we seem to apply the idiom of pathology to a variety of institutional problems only because we live in a highly medicalized society where distress is regarded as a purely individual phenomenon (Littlewood, 2001). Referring specifically to anorexia nervosa and the high incidence of deliberate overdose with prescribed drugs among women, Littlewood (2001) says it is difficult to separate the problem from those cultural or political patterns that may cause it, namely the context where female morphology is determined by men, and the medicalization of women. Female gender is a significant predictor in the prescription of mood-altering psychotropic drugs, according to the WHO (2013). Similar considerations apply to culture, race and ethnicity (Takeuchi \& Williams, 2003).

\section{A broader view of culture}

We argued above that cultural psychiatry tends to espouse the myth of the pathogenic/pathoplastic dichotomy, which holds that biology is responsible for the underlying structure of a malaise while cultural beliefs shape the specific ways in which a person experiences the malaise (Wallace, 2009). Whether cultural psychiatry is applied as cultural case formulation, or as sharing care with indigenous healers, the problem remains that cultural psychiatry's oversimplified framing of sociocultural processes is merely epiphenomenal and could result in essentialism, reductionism and ethnocentrism (Alarcón et 
al., 2009).

Heath (2001, p. 483-484) calls for a broader view of culture:

"It is unfortunate that too many people misconstrue culture as pertaining only to others - quaint and curious customs that people from distant or exotic places or disadvantaged backgrounds sometimes have. From this perspective, cultural sensitivity may be a nicety of interest to a few 'touchy-feely' humanists, but hardly a serious topic of concern for biomedical science."

In contrast, Heine (2001) proposes an explicit cultural psychology that does not view culture as a superficial wrapping of the self, or as a framework within which selves interact, but as something that is intrinsic to the self. In other words, without culture there is no self, only a biological entity deprived of its potential. Downey (2010) likewise proposes that there may be more intransigent organic dimensions of culture. The domain of the 'cultural' may be broader and less inherently conscious than just 'beliefs'. In this regard, Kohrt, Maharjan, Timsina, and Griffith (2012) recommend consideration of the growing field of neuroanthropology, which introduces the idea of the encultured brain.

\section{Neuroanthropolgy}

Neuroanthropology's core dynamic is the interaction of brain and culture as it explores the synthesis of nature and nurture (Lende \& Downey, 2009). Using social and cultural neuroscience in combination with psychological anthropology and cultural psychology, neuroanthropology blends in-depth analyses of both neurological function and ethnographic reality. The aforementioned leads to robust analyses of specific neural-cultural phenomena and has profound implications for our understanding of how inequality works through the brain and body involving mechanisms such as stress, learning environments, the loss of neuroplasticity, the impact of toxins, educational opportunities (or their absence) and other 
factors that negatively shape development.

The metaphor "poverty poisons the brain" highlights the impact of inequality and the embodiment of experience (Lende, 2012). A case in point is the high incidence of neuropsychiatric disorders related to malnutrition, political upheavals, natural disasters and the Human Immunosuppressive Virus (HIV)/Acquired Immunodeficiency Syndrome (AIDS) pandemic in Africa, and also manifested in increasing numbers of orphans and street children as well as increasing drug abuse and prostitution (Olatawura, 2001). Collura and Lende (2012) describe how individual-environment interactions, individual interpretations and sense of identity play a key role in the impact of trauma on and development (or not) of PTSD. A neuroanthropological approach can use ideas of neural plasticity and the encultured brain to link culture, interpretation and identity and the impact of trauma (Lende \& Downey, 2012a; 2012b).

\section{Evolutionary anthropology}

Evolutionary anthropologists Richerson and Boyd (2004) have revealed the nature-versusnurture debate as fundamentally misconceived and have illustrated that culture is neither superorganic nor the handmaiden of genes. Rather, culture is essential to human adaptation and is as much a part of our biology as bipedal locomotion. Indeed, linkages between epigenetics and psychopathology are emerging that point to new possibilities for conceptualizing, preventing and treating disorders (Masterpasqua, 2009).

Wallace $(2008 ; 2009)$ notes that the interplay of socioeconomic and environmental stressors involve complex patterns of symbolism. These information sources interact by a crosstalk that, over the life course, determines the ontology of the mind, including its manifold dysfunctions. The most important innovation may be the incorporation of culture as an essential component of the epigenetic regulation of mental development and the 
expression of mental disorders (Wallace, 2009). It is hoped that a precise understanding of the environmental contribution will provide us with the opportunity to intervene in nonpharmacological ways, such as enhancing parenting skills, to reduce psychopathology and disrupt the transmission of certain pathologies across generations (Ogren \& Lombroso, 2008).

The South African perspective South Africa is a nation of diversity with nearly 52 million people and a wide variety of cultures, languages and religious beliefs. Africans constitute $79.2 \%$ of the population; coloured and white people each 8.9\%; and the Indian/Asian population 2.5\% (South Africa.info, 2012). The DSM, like other classifications produced by professional bodies, is essentially a classification of the disorders seen and treated by contemporary American psychiatrists and clinical psychologists (Kendell, 2001). International psychiatry has consolidated its hegemonic hold over the territory of mental health and illness borne in the confidence of its neurobiological and presumably culture-free agenda (Fàbrega, 2001).

The South African Stress and Health (SASH) study (Herman et al., 2009) found that compared to the citizens of other countries, South Africans at the time of the study had relatively high prevalence rates of DSM disorders. One in six South Africans had a DSM disorder in the preceding 12 months, and one in three had a lifetime disorder. In comparison, one in 17 Nigerians had a DSM disorder in the preceding 12 months, and only one in 10 Nigerians had a lifetime DSM disorder. Compared to Nigerians, twice as many South Africans had lifetime anxiety disorders, four times as many had lifetime mood disorders and almost six times as many had substance use disorders.

Especially in South Africa, increasing the extent of the DSM-based diagnostic labelling and stigmatization of those who have already been subjected to racial stigmatizing 
would be questionable. More particularly, foregrounding neurobiological causes of emotional, social and learning deficits - while underplaying the massive impact of the reciprocal, dynamic, contextually influenced interaction between people and their emotional, cultural, economic, political and social ecologies - would be one more way of perpetuating the marginalization and suppression of those who have been made vulnerable (Chilisa, 2005), not to mention those multitudes of children who have been disadvantaged by gross deficits in the education system and/or who have been subjected to maltreatment and neglect (Kinard, 1998).

\section{Conclusion}

Irrespective of the great advances that have been made in understanding psychiatric classification and how these advances have been translated into the development of the DSM5, there are concerns that the DSM-5 will fail to address issues of diversity (Maldonado et al., 2011). One of the ongoing problems with the DSM classification system is the seeming lack of a theoretical/explanatory basis or an agreed-upon scientific model. From a scientific point of view, this just does not make sense. More progress is needed in culture-sensitive research and in understanding the complex and dynamic relationship between biological and sociocultural forces in the manifestation of psychopathology (Walsh \& Cross, 2013). Until then, the Jury will be out on what truly constitutes psychopathology across cultures.

\section{References}

Alarcón, R. D., Becker, A. E., Lewis-Fernández, R., Like, R. C., Desai, P., Foulks, E., Primm, A. (2009, August). Issues for DSM-V: The role of culture in psychiatric diagnosis: The Role of Culture in Psychiatric Diagnosis. The Journal of Nervous and Mental Disease, 197(8), 559-560. doi: 10.1097/NMD.0b013e3181b0cbff 
Ally, Y., \& Laher, S. (2008). South African Muslim faith healers perceptions of mental illness: Understanding aetiology and treatment. Journal of Religion and Health, 47(1), 45-56.

American Psychiatric Association (APA). 2013. Diagnostic and statistical manual of mental disorders (5th ed.). Arlington, VA: American Psychiatric Publishing.

Angell, M. (2011, July 14). The Illusions of Psychiatry. Retrieved fromThe New York Review of Books: http://www.nybooks.com/articles/archives/2011/jul/14/illusions-ofpsychiatry/?pagination $=$ false

Arnett, J. J. (2008, October). The neglected 95\%: Why American psychology needs to become less American.. The American Psychologist, 63(7), 602-614. doi: 10.1037/0003-066X.63.7.602

Barnett, R., \& Rivers, C. (2004). Same difference: How gender myths are hurting our relationships, our children, and our jobs. New York: Basic Books.

Bendelow, G. (2004). Sociology and concepts of mental illness. Philosophy, Psychiatry, \& Psychology, 11(2): 145-146. DOI: 10.1353/ppp.2004.0048

Berganza, C. E., Mezzich, J. E., Otero-Ojeda, A. A., Jorge, M. R., Villasenor-Bayardo, S. J., \& Rojas-Malpica, C. (2001, September). The Latin American guide for psychiatric diagnosis. A cultural overview. The Psychiatric Clinics of North America, 24(3), 433446.

Bhui, K. S., Dinos, S., Ashby, D., Nazroo, J., Wessely, S., \& White, P. D. (2011, March 21). Chronic fatigue syndrome in an ethically diverse population: the influence of psychosocial adversity and physical inactivity. BMC Medicine, 9(26):1-12. Retrieved September 26, 2013, from http://www.biomedcentral.com/content/pdf/1741-7015-926.pdf. doi: 10.1186/1741-7015-9-26 
Bhui, K., McKenzie, K., \& Gill, P. (2004). Delivering mental health services for a diverse society. British Medical Journal, 329(7462), 363-364. Retrieved September 26, 2013, from http://www.ncbi.nlm.nih.gov/pmc/articles/PMC509333/. doi: 10.1136/bmj.329.7462.363

Bhui, K., Mohamud, S., Warfa, N., Curtis, S., Stansfeld, S., \& Craig, T. (2012, April 17). Forced residential mobility and social support: impacts on psychiatric disorders among Somali migrants. BMC International Health and Human Rights, 12(4), 1-11. Retrieved September 26, 2013, from http://www.biomedcentral.com/content/pdf/1472-698X-12-4.pdf. doi: 10.1186/1472$698 X-12-4$

Blackman, L. (2004, May). Self-Help, Media Cultures and the Production of Female Psychopathology. European Journal of Cultural Studies, 7(2), 219-236. Retrieved September 26, 2013, from http://ecs.sagepub.com/content/7/2/219.abstract. doi: $10.1177 / 1367549404042496$

Blackman, L. (2007, June). Psychiatric Culture and Bodies of Resistance. Body Society, 13(2), 1-23. Retrieved September 26, 2013, from http://bod.sagepub.com/content/13/2/1.abstract. doi: 10.1177/1357034X07077770

British Psychological Society (BPS). (2011). The debate over DSM-5. Retrieved September 26, 2013, from British Psychological Society: http://www.bps.org.uk/

Cabassa, L. J. (2003, July). Integrating cross-cultural psychiatry into the study of mental health disparities. American Journal of Public Health, 93(7), 1034. Retrieved September 26, 2013, from http://www.ncbi.nlm.nih.gov/pmc/articles/PMC1447889/ Caplan, P. J. (n.d.). Psychiatric Diagnosis: Too Little Science, Too Many Conflicts of Interest. Retrieved September 26, 2013, from The Association for Women in Psychology: http://www.awpsych.org/index.php/bias-in-psychiatric-diagnosis-dsm-v- 
portal/74-bias-in-psychiatric-diagnosis-dsm-v/bias-in-psychiatric-diagnosis-dsmv/101-psychiatric-diagnosis-too-little-science-too-many-conflicts-of-interest

Caracci, G., \& Mezzich, J. E. (2001, September). Culture and urban mental health. The Psychiatric Clinics of North America, 24(3), 581-593.

Carroll, B. J. (2013, July). Biomarkers in DSM-5: Lost in translation. Australian \& New Zealand Journal of Psychiatry, 47(7), 676-678. Retrieved September 26, 2013, from http://anp.sagepub.com/content/47/7/676. doi: 10.1177/0004867413491162

Chilisa, B. (2005). Educational research within postcolonial Africa: A critique of HIV/AIDS research in Botswana. International Journal of Qualitative Studies in Education, 18(6), 659-684. Retrieved September 26, 2013, from http://ubrisa.ub.bw/jspui/bitstream/10311/54/1/chilisacolonization1.pdf. doi: $10.1080 / 09518390500298170$

Citizens Commission on Human Rights International (CCHR) (2013). Psychiatry’s Billing Bible: The Diagnostic and Statistical Manual of Mental Disorders (DSM). (2013). Retrieved September 26, 2013, from Citizens Commission on Human Rights International (CCHR): http://www.cchrint.org/cchr-issues/dsm-billing-bible/

Coalition for DSM-5 Reform. (n.d.). Retrieved September 26, 2013, from http://dsm5reform.com/

Collura, G. L., \& Lende, D. H. (2012, May). Post-traumatic stress disorder and neuroanthropology: Stopping PTSD before it begins [Special Issue: Neuroanthropology and Its Applications]. Annals of Anthropological Practice, 36(1), 131- 148. Retrieved September 26, 2013, from http://onlinelibrary.wiley.com/doi/10.1111/j.2153-9588.2012.01096.x/abstract. doi: 10.1111/j.2153-9588.2012.01096.x 
Cross, C., \& Walsh, K. (2012). Star shots: Stigma, self disclosure and celebrity inbipolar disorder. In J. Barnhill (Eds.), Bipolar Disorder - A Portrait of a Complex Mood Disorder (pp. 221-236). Rijeka: In Tech. Retrieved September 26, 2013, from http://ro.uow.edu.au/cgi/viewcontent.cgi?article=4115\&context=hbspapers

Davey, G. (2013, February 21). Criticisms of the DSM Development Process. Retrieved September 26, 2013, from Graham Davey’s Blog: http://grahamdavey.blogspot.com/2013/02/criticisms-of-dsm-developmentprocess.html

De Vos, J. (2010, August). Christopher Lasch's The Culture of Narcissism: The failure of a critique of psychological politics. Theory Psychology, 20(4), 528-548. Retrieved September 26, 2013, from http://tap.sagepub.com/content/20/4/528.abstract. doi: $10.1177 / 0959354309351764$

Dhar, M. (2013, May 2). Psychiatry's Contested Bible: How the new DSM Treats Addiction. Retrieved September 26, 2013, from Pacific Standard website: http://www.psmag.com/health/psychiatry-contested-bible-dsm-addiction-56953/

Dietrich, S., Beck, M., Bujantugs, B., Kenzine, D., Matschinger, H., \& Angermeyer, M. C. (2004). The relationship between public causal beliefs and social distance toward mentally ill people. Australian and New Zealand Journal of Psychiatry, 38(5), 348354.

Dinos, S., Khoshaba, B., Ashby, D., White, P. D., Nazroo, J., Wessely, S., \& Bhui, K. S. (2009, December). A systematic review of chronic fatigue, its syndromes and ethnicity: prevalence, severity, co-morbidity and coping. International Journal of Epidemiology, 38(6), 1554-1570. Retrieved September 26, 2013, from http://www.ncbi.nlm.nih.gov/pubmed/19349479. doi: 10.1093/ije/dyp147 
Downey, G. (2010, January 10). Exporting American mental illness. Retrieved September 26, 2013, from Neuroanthropology: http://neuroanthropology.net/2010/01/10/exportingamerican-mental-illness/

Duniec, E., \& Raz, M. (2011, March). Vitamins for the soul: John Bowlby's thesis of maternal deprivation, biomedical metaphors and the deficiency model of disease. History of Psychiatry, 22(85 Pt 1), 93-107.

Fàbrega, H. (2001, September). Cultural psychiatry: international perspectives. Epilogue. The Psychiatry Clinics of North America, 24(3), 595-608.

Fassaert, T., Peen, J., Van Straten, A., De Wit, M., Schrier, A., Heijen, H.,...Dekker, J. (2010, July 01). Ethnic differences and similarities in outpatient treatment for depression in the Netherlands. Psychiatric Services, 61(7), 690-697. Retrieved September 26, 2013, from http://ps.psychiatryonline.org/data/Journals/PSS/3912/10ps690.pdf. doi: 10.1176/appi.ps.61.7.690

Fine, C. (2011). Delusions of Gender: The real science behind sex differences.. London: Icon Books.

First, M. B. (2010, November). Paradigm shifts and the development of the diagnostic and statistical manual of mental disorders: past experiences and future aspirations. Canadian Journal of Psychiatry, 55(11), 692-700.

Frances, A. (2013). The New Crisis in Confidence in Psychiatric Diagnosis. Annals of Internal Medicine, 1-2. Retrieved September 26, 2013, from http://www.medpagetoday.com/upload/2013/5/17/0000605-201308060-00655-1.pdf

Friedman, R. A. (2012, September 24). A Call for Caution on Antipsychotic Drugs. Retrieved September 26, 2013, from The New York Times: 
http://www.nytimes.com/2012/09/25/health/a-call-for-caution-in-the-use-of-

antipsychotic-drugs.html? $\mathrm{r}=0$

Goldarce, B. (2010, October 8). The stigma gene. Retrieved April 7, 2013, from Bad Science: http://www.badscience.net/category/neuro-nonsense/

Heath, D. B. (2001, September). Culture and substance abuse. The Psychiatric Clinics of North America, 24(3), 479-496.

Hebebrand, J., \& Bulik, C. M. (2011, December).Critical appraisal of the provisional DSM-5 criteria for anorexia nervosa and an alternative proposal. International Journal of Eating Disorders, 44(8), 665-678. Retrieved September 26, 2013, from http://0web.ebscohost.com.innopac.up.ac.za/ehost/pdfviewer/pdfviewer?sid=5d2c445e-07724e02-80df-ac86806cbabb\%40sessionmgr113\&vid=2\&hid=126. doi:

10.1002/eat.20875

Heine, S. J. (2001). Self as cultural product: an examination of East Asian and North American selves. Journal of Personality, 69(6), 881-906. Retrieved September 26, 2013, from http://www2.psych.ubc.ca/ heine/docs/2001asianself.pdf

Herman, A. A., Stein, D. J., Seedat, S., Heeringa, S. G., Moomal, H., \& Williams, D. R. (2009, May). The South African Stress and Health (SASH) study: 12-month and lifetime prevalence of common mental disorders. South African Medical Journal, 99(5 Pt 2), 339-344. Retrieved September 26, 2013, from http://www.ncbi.nlm.nih.gov/pmc/articles/PMC3191537/pdf/nihms327590.pdf

Hinton, D. E., \& Lewis-Fernández, R. (2011, September). The cross-cultural validity of posttraumatic stress disorder: implications for DSM-5. Depression and Anxiety, 28(9), 783-801. doi: 10.1002/da.20753

Hughes, C. C. (1993). Culture in clinical psychiatry. In A. C. Gaw (Ed.), Culture, ethnicity and mental illness (pp. 3-42). Washington, DC: American Psychiatric Press. 
Jablensky, A. (2012, September). The disease entity in psychiatry: fact or fiction?

Epidemiology and Psychiatric Sciences, 21(3), 255-264. Retrieved September 26, 2013, from

http://journals.cambridge.org/download.php?file=\%2F30383_214064793D5DDC76D E2AC40EAF5CDE35_journals_EPS_EPS21_03_S2045796012000339a.pdf\&cover $=\mathrm{Y} \& \operatorname{code}=9297 \mathrm{~b} 87 \mathrm{be} 92379 \mathrm{c} 0454 \mathrm{f} 2789 \mathrm{ffa} 4 \mathrm{ab} 4 \mathrm{~d}$. doi: $10.1017 / \mathrm{S} 20457901200039$

Jabr, F. (2013, January 28). The Newest Edition of Psychiatry's “Bible, ” the DSM-5, Is

Complete. Retrieved September 26, 2013, from Scientific American:

http://www.scientificamerican.com/article.cfm?id=dsm-5-update

Joyce, P. R. (2008). Classification of mood disorders in DSM-V and DSM-VI. Australian and New Zealand Journal of Psychiatry, 42(10), 851-862. Retrieved September 26, 2013, from http://informahealthcare.com/doi/abs/10.1080/00048670802363667. doi: $10.1080 / 00048670802363667$

Kecmanovic, D. (2012, December). The future of psychiatry. Australas Psychiatry, 20(6), 467-471. Retrieved September 26, 2013, from http://apy.sagepub.com/content/20/6/467.abstract. doi: 10.1177/1039856212460285

Kendell, R. E. (2001). The distinction between mental and physical illness. The British Journal of Psychiatry, 178, 490-493. Retrieved September 26, 2013, from http://bjp.rcpsych.org/content/178/6/490.full. doi: 10.1192/bjp.178.6.490

Kesler, R. C., Chiu, W. T., Demler, O., \& Walters, E. E. (2005, June). Prevalence, Severity, and Comorbidity of Twelve-month DSM-IV Disorders in the National Comorbidity Survey Replication (NCS-R). Arch Gen Psychiatry, 62(6), 617-627. Retrieved September 26, 2013, from http://www.ncbi.nlm.nih.gov/pmc/articles/PMC2847357/pdf/nihms176704.pdf. doi: 10.1001/archpsyc.62.2.617 
Kinard, E. M. (1998, July). Methodological issues in assessing resilience in maltreated children. Child Abuse and Neglect, 22(7), 669-680.

Kirschner, S. R. (2013). Diagnosis and its discontents: Critical perspectives on psychiatric nosology and the DSM. Feminism \& Psychology, 23(1): 10-28. Retrieved September 26, 2013, from http://fap.sagepub.com/content/23/1/10.full.pdf. doi: $10.1177 / 0959353512467963$

Kohrt, B. A., Maharjan, S. M., Timsina, D., \& Griffith, J. L. (2012, May). Applying nepali ethnopsychology to psychotherapy for the treatment of mental illness and prevention of suicide among Bhutanese refugees [Special Issue: Neuroanthropology and Its Applications]. Annals of Anthropological Practice, 36(1), 88-112. Retrieved September 26, 2013, from http://onlinelibrary.wiley.com/doi/10.1111/j.21539588.2012.01094.x/abstract. doi: 10.1111/j.2153-9588.2012.01094.x

Kutchins, H., \& Kirk, S. A. (1997). Making Us Crazy: DSM: The Psychiatric Bible and the Creation of Mental Disorders. New York: Free Press.

Lane, C. (2013, May 4). The NIMH Withdraws Support for DSM-5: The latest development is a humiliating blow to the APA. Retrieved September 26, 2013, from Psychology Today: http://www.psychologytoday.com/blog/side-effects/201305/the-nimhwithdraws-support-dsm-5

Lasch, C. (1978). The culture of narcissism: American life in an age of diminishing expectations. New York: W. W. Norton.

Lee, S. (2001, September). From diversity to unity. The classification of mental disorders in 21st-century China. Psychiatry Clinics of North America, 24(3), 421-431.

Lee, S. (2002, Mar-Jun). Socio-cultural and global health perspectives for the development of future psychiatric diagnostic systems. Psychopathology, 35(2-3), 152-157. 
Lempérière, T. (1995, December). The importance of classifications in psychiatry. Encephale, 21(5), 3-7.

Lende, D. H. (2012, May). Poverty poisons the brain [Special Issue: Neuroanthropology and Its Applications]. Annals of Anthropological Practice, 36(1), 183-201. Retrieved September 26, 2013, from http://onlinelibrary.wiley.com/doi/10.1111/j.21539588.2012.01099.x/abstract. doi: 10.1111/j.2153-9588.2012.01099.x

Lende, D. H., \& Downey, G. (2012a, May). Neuroanthropology and its applications: an introduction [Special Issue: Neuroanthropology and Its Applications]. Annals of Anthropological Practice, 36(1), 1-25. Retrieved September 26, 2013, from http://onlinelibrary.wiley.com/doi/10.1111/j.2153-9588.2012.01090.x/abstract. doi: 10.1111/j.2153-9588.2012.01090.x

Lende, D. H., \& Downey, G. (Eds.). (2012b). The encultured brain: An introduction to Neuroanthropology. Cambridge, MA: MIT Press.

Lende, D., \& Downey, G. (2009, October 8-9). The Encultured Brain: Interdisciplinary Collaborations for the Future of Neuroanthropology. Retrieved September 26, 2013, from Society for Psychological Anthropology: http://www.aaanet.org/sections/spa/?page_id=329

Levine, S. (2013). The self-deceptions and misconceptions of psychiatrists, psychologists, and other mental health professionals. In L. T. Flaherty (Ed.), Adolescent Psychiatry: The annals of the American Society for Adolescent Psychiatry (Volume 27) (pp. 325). Hillsdale, NJ: The Analytic Press.

Lewis-Fernández, R., Hinton, D. E., Laria, A. J., Patterson, E. H., Hofmann, S. G., Craske, M. G.,...Liao, B. (2010, February). Culture and the anxiety disorders: Recommendations for DSM-V. Depression and anxiety, 27(2), 212-229. doi: 10.1002/da.20647 
Lilienfeld, S. O., \& Arkowitz, H. A. (2009, November 19). Foreign Afflictions: Mental Disorders across Country Borders. Retrieved September 26, 2013, from Scientific American: www.scientificamerican.com/article.cfm?id=foreign-afflictions

Lim, R. (2013, October 16). What's New in DSM-5 for Cultural Psychiatry? Retrieved May 8, 2014, from Psychiatric News:

http://psychnews.psychiatryonline.org/newsarticle.aspx?articleid=1757008. doi: 10.1176/appi.pn.2013.10b12

Lin, K. M., Smith, M. W., \& Ortiz, V. (2001, September). Culture and psychopharmacology. The Psychiatric Clinics of North America, 24(3), 523-538.

Littlewood, R. (1996, Winter). Psychiatry's Culture. International Journal of Social Psychiatry, 42(2), 245-268.

Littlewood, R. (2001). Psychotherapy in cultural contexts. The Psychiatric Clinics of North America, 24(3), 507-522.

López-Ibor, J. J. (2003, May-June). Cultural adaptations of current psychiatric classifications: are they the solution? Psychopathology, 36(3), 114-119.

López-Muñoz, F., Alamo, C., Quintero-Gutiérrez, F. J., \& García-García, P. (2008, September). A bibliometric study of international scientific productivity in attentiondeficit hyperactivity disorder covering the period 1980-2005. European Child \& Adolescent Psychiatry, 17(6), 381-391. Retrieved September 26, 2013, from http://0web.ebscohost.com.innopac.up.ac.za/ehost/detail?sid=ed4ad5f3-c57f-4ed9-93ebead96b0d0c34\%40sessionmgr113\&vid=1\&hid=126\&bdata=JnNpdGU9ZWhvc3Qtb G12ZSZzY29wZT1zaXRl\#db=aph\&AN=34284223. doi: 10.1007/s00787-008-0680-1 Loudon, J. (1959). Psychogenic disorder and social conflict among the Zulu. In M. K. Opler (Ed.), Culture and mental health (pp. 351-369). New York: Macmillan. 
Maldonado, G. G., González, A. H. S., Castillo, A. L., \& Juárez, I. G. S. (2011). The DSMV.Lights and shadows of a yet unpublished manual. Challenges and expectations for the future. Salud Mental, 34(4):363-373. Retrieved September 26, 2013, from http://www.saludmental.edilaser.net/en/pdf/3404/SM_11_04_09_En_p363-373.pdf

Martínez-Hernáez, A. (2006, November). When ants crawl around in the brain: challenges and facts in cultural psychiatry. Cad Saude Publica, 22(11), 2269-2280. Retrieved September 26, 2013, from http://www.ncbi.nlm.nih.gov

Masterpasqua, F. (2009). Psychology and Epigenetics. Review of general psychology, 13(3), 194-201.

Messich, J. E., Berganza, C. E., \& Ruiperez, M. A. (2001). Culture in DSM-IV, ICD-10, and evolving diagnostic systems. The Psychiatric Clinics of North America, 24(3), 407419.

Ogren, M. P., \& Lombroso, P. J. (2008, March). Epigenetics: Behavioral Influences on Gene Function, Part I. Maternal Behavior Permanently Affects Adult Behavior in Offspring. Journal of American Academy of Child and Adolescent Psychiatry, 47(3), 240-244. doi: 10.1097/CHI.0b013e3181635e13

Olatawura, M. (2001, September). Culture and child psychiatric disorders: A Nigerian perspective. The Psychiatric Clinics of North America, 24(3), 497-504.

Phelan, J. C. (2002, August). Genetic bases of mental illness - a cure for stigma? Trends in Neurosciences, 25(8), 430-431.

Profit, W. E. (2004). Should racism be classified as a mental illness? In P. J. Caplan, \& L. Cosgrove (Eds.), Bias in psychiatric diagnosis (pp. 81-88). Lanham: Rowman \& Littlefield Publishers. Retrieved September 26, 2013, from http://batstar.net/drama/bias.pdf 
Rasmussen, A. (2012, May 13). Proposed DSM-5 Cultural Formulation guidelines: A report from the SSPC [Web log message]. Retrieved September 26, 2013, from http://andyrasmussen.wordpress.com/2012/05/13/proposed-dsm-5-culturalformulation-guidelines-a-report-from-the-sspc/

Read, J., Haslam, N., Sayce, L., \& Davies, E. (2006). Prejudice and schizophrenia: a review of the 'mental illness is an illness like any other' approach. Acta Psychiatrica Scandinavica, 114, 303-318. Retrieved September 26, 2013, from http://www.theicarusproject.net/files/read_prejudice_schizophrenia_biol_stigma.pdf. doi: 10.1111/j.1600-0447.2006.00824.x

Rhi, B. Y. (2001, September). Culture, spirituality, and mental health. The forgotten aspects of religion and health. The Psychiatric Clinics of North America, 24(3), 569-579.

Richerson, P. J., \& Boyd, R. (2004). Not by Genes Alone: How Culture Transformed Human Evolution. Chicago: Chicago University Press.

Rossier, J., Ouedraogo, A., Dahourou, D., Verardi, S., \& De Stadelhofen, F. M. (2013). Personality and personality disorders in urban and rural Africa: results from a field trial in burkina faso. Frontiers in Psychology, 4, 79. Retrieved September 26, 2013, from http://www.ncbi.nlm.nih.gov/pmc/articles/PMC3593679/pdf/fpsyg-0400079.pdf. doi: 10.3389/fpsyg.2013.00079

Seaman, J. E. (2013). Gorilla in the waiting room: The daunting task of harnessing mental disorders. United States of America: Xlibris Corporation.

SouthAfrica.info. (2012, November 7). South Africa's population. Retrieved September 26, 2013, from SouthAfrica.info: http://www.southafrica.info/about/people/population.htm\#.UYYkj7_rbzI

Strand, M. (2011). Where do classifications come from? The DSM-III, the transformation of American psychiatry, and the problem of origins in the sociology of knowledge. 
Theory and Society, 40, 273-323. Retrieved September 26, 2013, from

http://link.springer.com/content/pdf/10.1007\%2Fs11186-011-9142-8.pdf. doi:

\section{$10.1007 / \mathrm{s} 11186-011-9142-8$}

Takeuchi, D. T., \& Williams, D. R. (2003, September). Race, ethnicity and mental health: Introduction to the special issue. Journal of Health and Social Behavior, 44(3), 233236. Retrieved September 26, 2013, from http://www.isr.umich.edu/williams/All\%20Publications/DRW\%20pubs\%202003/race ,\%20ethnicity,\%20and\%20mental\%20health.pdf

Toor, A. (2013, April 19). Controversial update to 'bible' of psychiatry fuels debate over foundations of mental health: One book raises big questions. Retrieved September 26, 2013, from The Verge website: http://www.theverge.com/2013/4/19/4243060/dsm-5bible-of-psychiatry-mental-health-revisions-spark-boycott

Turner, M. A. (2003). Psychiatry and the human sciences. The British Journal of Psychiatry, 182, 472-474. Retrieved September 26, 2013, from http://bjp.rcpsych.org/content/182/6/472.full. doi: 10.1192/02-244

Vanheule, S. (2012). Diagnosis in the field of psychotherapy: A plea for an alternative to the DSM-5.x. Psychology and Psychotherapy: Theory, Research and Practice, 85(2), 128-142. Retrieved September 26, 2013, from http://onlinelibrary.wiley.com/doi/10.1111/j.2044-8341.2012.02069.x/abstract. doi: 10.1111/j.2044-8341.2012.02069.x

Vukic, A., Gregory, D., Martin-Misener, R., \& Etowa, J. (2011). Aboriginal and Western Conceptions of Mental Health and Illness. Pimatisiwin: A Journal of Aboriginal and Indigenous Community Health, 9(1), 65-86. Retrieved September 26, 2013, from http://www.pimatisiwin.com/online/wpcontent/uploads/2011/08/04VukicGregory.pdf 
Wakefield, J. C. (2010). Misdiagnosing normality: Psychiatry's failure to address the problem of false positive diagnoses of mental disorder in a changing professional environment. Journal of Mental Health, 19(4), 337-351. doi: 10.3109/09638237.2010.492418

Wallace, R. (2008). Developmental disorders as pathological resilience domains. Ecology and Society, 13(1), 29. Retrieved September 26, 2013, from http://www.ecologyandsociety.org/vol13/iss1/art29/

Wallace, R. (2009, October 14). The cultural epigenetics of psychopathology: The missing heritability of complex diseases found? Retrieved September 26, 2013, from Cogprints: http://cogprints.org/6658/1/mdis12a.pdf

Walsh, K., \& Cross, W. (2013). Depression: Classification, Culture and the Westernisation of Mental Illness. In N. Kocabasoglu (Ed.), Mood Disorders (pp. 47-59). InTech. Retrieved September 26, 2013, from http://cdn.intechopen.com/pdfs/42233/InTechDepression_classification_culture_and_the_westernisation_of_mental_illness.pdf

Watters, E. (2010). Crazy Like Us: The Globalization of the American Psyche. United States of America: Free Press.

Wedge, M. (2011, May 23). Six Problems wih Psychiatric Diagnosis for Children. Retrieved September 26, 2013, from Psychology Today:

http://www.psychologytoday.com/blog/suffer-the-children/201105/six-problems-wihpsychiatric-diagnosis-children

Wintrob, R. (2010, January 10). Introduction: Cross-cultural Psychiatry. Retrieved April 2, 2013, from Psychiatric Times: www.psychiatrictimes.com/articles/introduction-crosscultural-psychiatry

World Health Organization (WHO). (2013). Why Gender and women's health? Retrieved September 26, 2013, from www.who.int/gender/genderandwomen/en/ 